\title{
Extraction, Structural Characterization, and Biological Functions of Lycium Barbarum Polysaccharides: A Review
}

\author{
Xiaojing Tian ${ }^{1,2,+}$, Tisong Liang ${ }^{1,2,+} \mathbb{D}$, Yuanlin Liu ${ }^{1,2}$, Gongtao Ding ${ }^{1}$, Fumei Zhang ${ }^{1,2}$ and \\ Zhongren Ma ${ }^{1,2, *}$ \\ 1 China-Malaysia National Joint Laboratory, Biomedical Research Center, Northwest Minzu University, \\ Lanzhou 730124, China \\ 2 College of Life Science and Engineering, Northwest Minzu University, Lanzhou 730124, China \\ * Correspondence: mzr@xbmu.edu.cn \\ + These authors contributed equally to this work.
}

Received: 30 July 2019; Accepted: 19 August 2019; Published: 21 August 2019

Abstract: Lycium barbarum polysaccharides (LBPs), as bioactive compounds extracted from L. barbarum L. fruit, have been widely explored for their potential health properties. The extraction and structural characterization methods of LBPs were reviewed to accurately understand the extraction method and structural and biological functions of LBPs. An overview of the biological functions of LBPs, such as antioxidant function, antitumor activity, neuroprotective effects, immune regulating function, and other functions, were summarized. This review provides an overview of LBPs and a theoretical basis for further studying and extending the applications of LBPs in the fields of medicine and food.

Keywords: Lycium barbarum polysaccharides; structural characterization; antitumor activity; antioxidant activity; immune regulation

\section{Introduction}

Lycium barbarum L., known as the wolfberry or goji berry, the fruits derived from Lycium barbarum $L$, are a local food that is widely distributed in the arid and semi-arid regions of China, Korea, Japan, Europe, North America, and the Mediterranean. Currently, China is the largest world producer with its 82,000 ha of cultivated land and 95,000 $\mathrm{t}$ of berries produced per year. The earliest use of the goji berry as a medicinal plant was at around 2300 years ago [1]. L. barbarum L. fruit is used as a traditional Chinese herbal medicine and functional food in daily life [2,3].

Three Lycium species (L. barbarum, L. chinense, and L. ruthenicum) have been discovered. Among the three species, the yield of Lycium barbarum is the largest in China. They are used as medicine in China and as medicinal and functional food because of their health benefits, including anti-aging, antioxidant, antidiabetic, anticancer, cytoprotective, neuroprotective, and immunomodulatory effects [4-9]. The physical appearance of Lycium barbarum is shown in Figure 1. The fruit is red and about 1-2 cm long. Numerous reports have been conducted to explore the function and characterization of its extracts because of the health benefits of Lycium barbarum. More than 200 different components, including carotenoids, phenylpropanoids, flavonoids, polyphenols, and polysaccharides, have been identified, characterized, and analyzed. Polysaccharides, vitamins, betaine, and mixed extracts of the goji berry are responsible for health benefits, such as eliciting anti-aging effects, improving eyesight, and exhibiting antifatigue effects [10].

Among Lycium barbarum extracts, L. barbarum polysaccharides (LBPs) isolated from L. barbarum fruit have been responsible for the biological activities of Lycium barbarum. LBPs are a group of 
water-soluble glycoconjugates with a molecular weight of 10-2300 kDa and comprise 5-8\% of the dried fruits [11]. The beneficial health effects of LBPs, including antioxidant and antiaging effects, increased metabolism, antiglaucoma effects, immune regulation, anticancer effects, neuroprotective properties, and antidiabetic effects, have been reported [12-16]. According to the Chinese understanding of Lycium extracts and products, the content of LBPs is important for the efficacy of L. barbarum [17-19]. Therefore, as bioactive constituents of L. barbarum, LBPs have many biological functions to improve people's health. The biological functions of LBPs are complex and multifaceted because of the relationship between the physiological structure and functions of LBPs. The relationship and mechanism between LBPs and human health should be fully understood. In order to give a comprehensive understanding of LBPS, the extraction methods, structure, composition, and biological functions of LBPs were summarized and discussed in this review. We collected and summarized the relative contents from previous reports to provide a theory basis for comprehensively understanding and utilizing LBPs in medical and food fields.
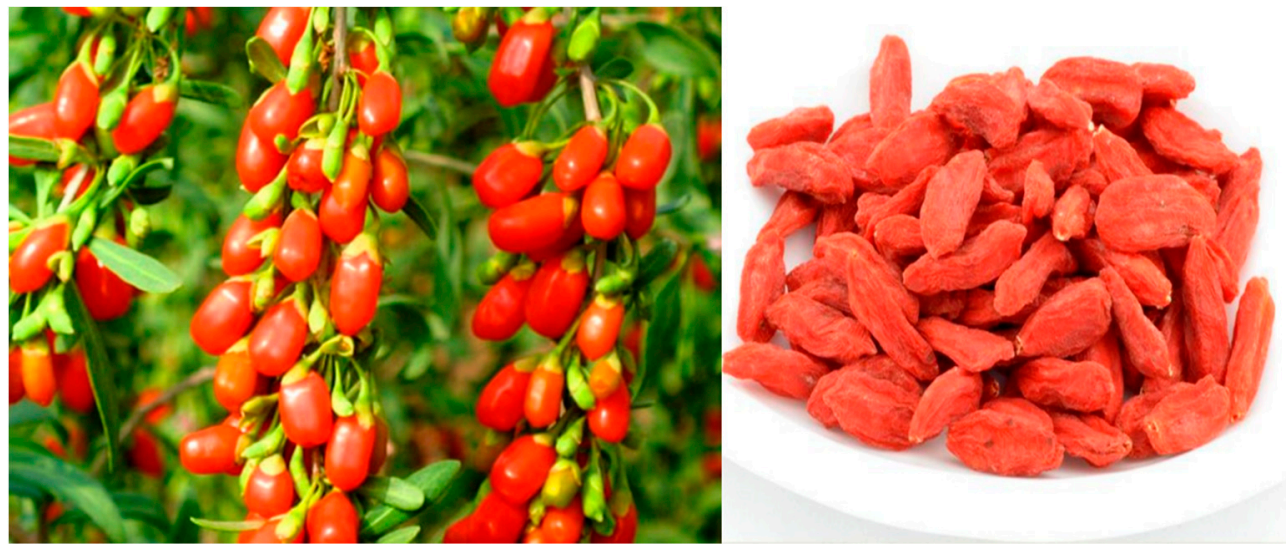

Figure 1. The fresh (left) and dried form (right) of Lycium barbarum fruit.

\section{Extraction Methods of LBPs}

Previous reports have shown that the chemical ingredients of L. barbarum fruit include polysaccharides, proteins, and phenylpropanoids. Among these ingredients, LBPs account for $5-8 \%$ of the dried fruit and elicit biological effects [2]. LBPs are subjected to extraction, purification, and analysis. The flowchart of the extraction, purification, and analysis of LBPs is shown in Figure 2.

LBPs are extracted by destroying and degrading the cell wall under mild conditions without changing the properties of the polysaccharides in accordance with basic extraction principles [20]. Many LBP extraction methods, such as the water extraction method, enzyme-assisted extraction method, microwave-assisted extraction method, ultrasonic-assisted extraction method, and supercritical fluid extraction method, have been developed on the basis of this principle [21,22]. Traditional LBP extraction methods have some advantages and disadvantages. Novel LBP extraction technologies, such as ultrasound-assisted extraction method (UAE) [23,24], enzyme-assisted extraction method (EAM) [25,26], microwave-assisted extraction method (MAM) [27], and supercritical fluid extraction method (SFM) [28], have been developed to address the disadvantages of traditional extraction methods. The high extraction yield and high biological activity of LBPs are considered in choosing an extraction method [29].

These extraction methods have unique strengths and weaknesses [21]. Hot water extraction (HWE) is the traditional method for polysaccharide extraction. The yield of HWE is largely affected by extraction time, temperature, and the ratio of water to raw material. Also, the long duration and high temperature may lead to the degradation of the polysaccharides and decrease their biological activity. EAM possesses the advantages of environmental friendliness, high efficiency, ease of operation, and low investment cost and energy. However, the enzyme is characterized by specificity and 
selectivity, while several factors, such as enzyme concentration, temperature, time, and $\mathrm{pH}$ also affect the biological function of polysaccharides. MAM is a physical technique that is used for the extraction of polysaccharides. MAE has noticeable advantages, such as shorter extraction time, higher extraction yield, lower cost, and less solvent consumption. UAM has the advantage of improving penetration and capillary effects, leading to an increase of polysaccharides' extractability. However, ultrasonic treatment could affect the structure and molecular weight (MW) of polysaccharides, which would cause a change in the biological activity. The extraction conditions and yield of LBP extract by different extraction methods are shown in Table 1.

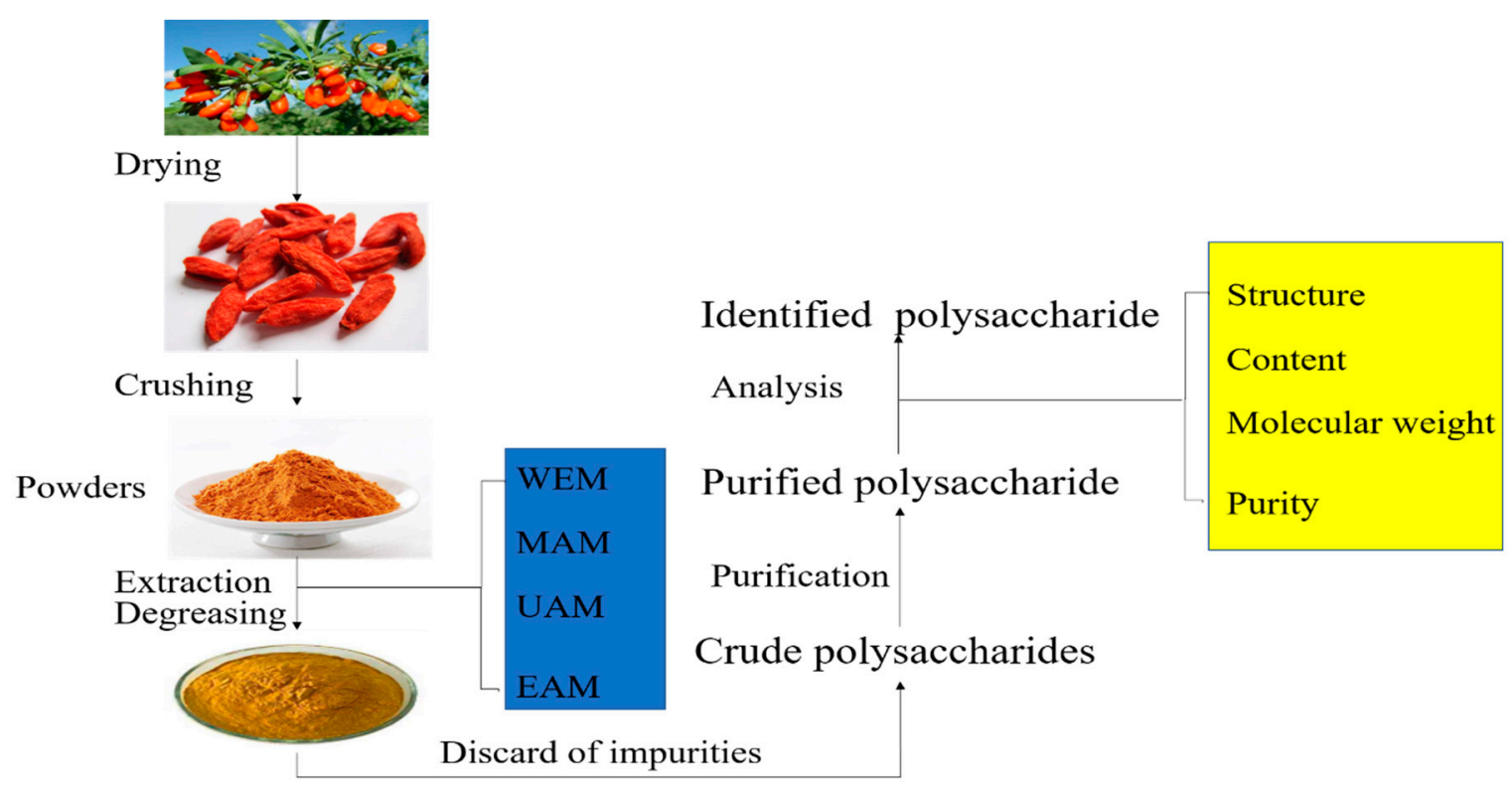

Figure 2. The flowchart of the extraction, purification, and analysis of Lycium barbarum polysaccharides (LBPs). WEM: water extraction method, EAM: enzyme-assisted extraction method, MAM: microwave-assisted extraction method, UAM: ultrasonic-assisted extraction method.

As the traditional extraction method is widely used in the extraction of LBPs, the yield of the water extraction method (WEM) is 5.87\% under the experimental conditions [30]. The yields of LBPs via UAM, EAM, and MAM are 2.286-5.701\%, 6.81\% $\pm 0.10 \%$, and $8.25 \% \pm 0.07 \%$, respectively [31-35]. The yield of LBPs of novel extraction methods is higher than that of the water extraction method. Moreover, the combination of different extraction methods can obtain enhanced yields of LBPs; when the ultrasound-enhanced subcritical water extraction method (USWE) is used to extract the LBPs, high recovery yields of LBPs are produced [24]. 
Table 1. Summary of the extraction methods on the extraction of LBPs.

\begin{tabular}{|c|c|c|c|}
\hline Extraction Methods & Extraction Conditions & Yield (\%) & Ref \\
\hline Water extraction method & The ratio liquid to solid $70: 1, \mathrm{pH} 10$, at $65^{\circ} \mathrm{C}$, extracted in soakage for $3.5 \mathrm{~h}$. & 7.46-7.63\% & {$[30,34,35]$} \\
\hline Ultrasound-assisted extraction method & Extraction time of $30 \mathrm{~min}$, temperature of $60^{\circ} \mathrm{C}$, solid/liquid ratio of $20 \mathrm{~g} / 600 \mathrm{~mL}$, power density of $300 \mathrm{~W} / \mathrm{L}$, ultrasound frequency of $28 \mathrm{kHz}$. & $2.286-5.701 \%$ & {$[23,36]$} \\
\hline Enzyme-assisted extraction method & Extraction time of $91 \mathrm{~min}$, extraction temperature of $59.7^{\circ} \mathrm{C}, \mathrm{pH} 5.0$. & $6.81 \pm 0.10 \%$ & [26] \\
\hline Microwave-assisted extraction method & Ratio of water to raw material of $31.5 \mathrm{~mL} / \mathrm{g}$, extraction time of $25.8 \mathrm{~min}$, microwave power of $544.0 \mathrm{~W}$. & $8.25 \pm 0.07 \%$ & [27] \\
\hline Combination of extraction methods & Temperature of $100^{\circ} \mathrm{C}$, extraction time of $53 \mathrm{~min}$, liquid-to-solid ratio of $26 \mathrm{~mL} / \mathrm{g}$, ultrasonic electric power of $160 \mathrm{~W}$. & $5.728 \%$ & [24] \\
\hline
\end{tabular}




\section{Structure and Composition of LBPs}

The separation and structural characterization methods of purified LBPs have been developed. As active ingredients, LBPs possess various biological functions. More than 33 polysaccharides have been analyzed and identified from L. barbarum $L$.

The main applied and performance techniques for the structural characterization of LBP fraction include the following techniques: (1) high-performance gel permeation chromatography (HPGPC), which is used to determine the homogeneity and molecular weight of macromolecules; (2) partial acid or enzymatic hydrolysis, oxidation with periodic acid, Smith degradation, high-performance liquid chromatography (HPLC), gas chromatography (GC), polysaccharide analysis by gel electrophoresis (PACE), and high-performance thin-layer chromatography (HPTLC). These techniques are used to determine monosaccharide composition and map the glycidic component of glycoconjugates; (3) infrared (IR) spectral analysis permits the identification of pyranosyl or furanosyl ring form and $\alpha$ or $\beta$ anomeric configuration in monosaccharide residues; (4) ${ }^{1} \mathrm{H}$ and ${ }^{13} \mathrm{C}$ nuclear magnetic resonance (NMR) spectroscopy used to assign the ratios of monosaccharides present and ratios of their anomeric bonds; (5) gas chromatography-mass spectrometry (GC-MS), employed to determine the linkage positions.

Studies have widely explored the structure and composition of LBPs and demonstrated that LBPs are polysaccharides, including some ingredients of acidic heteropolysaccharides, polypeptides, or proteins [37]. The molecular weight of LBPs at the range of 10-2300 kDa. The methods used for the isolation and purification of LBPs from L. barbarum include DEAE ion-exchange cellulose, gel-permeation chromatography, and high-performance liquid chromatography (HPLC) [31,38]. About 20 types of polysaccharides, including Rha, Fuc, Ara, Gal, and GalA, have been investigated. Studies have shown that monosaccharide and amino acid residues constitute glycoconjugates, and, relative to glycosidic linkage analysis of glycan backbone, branching sites and side chains were considered as the structure of LBPs. The possible structure of repeat units, molecular weights, and analysis technique of previously investigated polysaccharides in L. barbarum are shown in Table 2. 
Table 2. The possible structure of repeat units, molecular weights, and analysis technique of polysaccharides in L. barbarum [39] Definitions: SEC = size exclusive chromatography, GC-MS = gas chromatography-mass spectrometry, NMR = nuclear magnetic resonance, IR = infrared, GC = gas chromatography, ESI-MS = electrospray ionization mass spectrometry, HPGPC = high-performance gel permeation chromatography.

\begin{tabular}{|c|c|c|c|c|c|c|}
\hline No & Name & Mw (kDa) & Molar Ratio & Analysis Technique & Possible Structure of Repeat Unit & Ref \\
\hline 1 & LbGp2 & 68,200 & Ara:Gal = 4:5 & SEC, GC-MS & $\begin{array}{l}\text { Backbone composed of }(1 \rightarrow 6) \text { - } \beta \text {-Gal. Branches composed of }(1 \rightarrow 3) \text { - } \beta \text {-Ara and }(1 \rightarrow 3) \text { - } \beta \text {-Gal terminated } \\
\text { with }(1 \rightarrow 3) /(1 \rightarrow 5)-\alpha \text {-Ara. }\end{array}$ & [40] \\
\hline 2 & LbGp3 & 92,500 & Ara:Gal = 1:1 & NMR & $\begin{array}{l}\text { Backbone composed of }(1 \rightarrow 4) \text { - } \beta \text {-Gal. Branches composed of }(1 \rightarrow 3) \text { - } \beta \text {-Ara and }(1 \rightarrow 3)-\alpha \text {-Gal terminated } \\
\text { with }(1 \rightarrow 3) /(1 \rightarrow 5) \text { - } \alpha \text {-Ara. }\end{array}$ & [41] \\
\hline 3 & LbGp4 & 214,800 & $\begin{array}{l}\text { Ara:Gal:Rha:Glc }= \\
\text { 1.5:2.5:0.43:0.23 }\end{array}$ & NMR & $\begin{array}{l}\text { Backbone composed of }(1 \rightarrow 4) \text { - } \beta \text {-Gal. Branches composed of }(1 \rightarrow 3) \text { - } \beta \text {-Gal terminated with (1 } \rightarrow 3) \text { - } \alpha \text {-Ara } \\
\text { and }(1 \rightarrow 3) \text { - } \beta \text {-Rha. }\end{array}$ & [42] \\
\hline 4 & LBPA3 & 66,000 & Ara:Gal = 1.2:1 & Ion exchange chromatography & Heteropolysaccharide with $(1 \rightarrow 4),(1 \rightarrow 6)$ & \multirow{2}{*}{ [43] } \\
\hline 5 & LBPB1 & 18,000 & Ara:Glc $=1: 3.1$ & & Heteropolysaccharide with $(1 \rightarrow 4),(1 \rightarrow 6) \beta$-glycosidic bond. & \\
\hline 6 & LBP-a4 & 10,200 & Fuc: gal = 0.41:1 & Ultrafiltration membrane method & & [43] \\
\hline 7 & LBPC2 & 12,000 & Xyl:Rha:Man = 8.8:2.3:1 & & Heteropolysaccharide with $(1 \rightarrow 4),(1 \rightarrow 6) \beta$-glycosidic bond. & [44] \\
\hline 8 & LBPC4 & 10,000 & Glc & IR, GC & Heteropolysaccharide with $(1 \rightarrow 4),(1 \rightarrow 6) \alpha$-glycosidic bond. & [45] \\
\hline 9 & LBP1a-1 & 115,000 & Glc & & $\alpha$-(1-6)- D-glucan. & \multirow{4}{*}{ [46] } \\
\hline 10 & LBP1a-2 & 94,000 & Glc & & 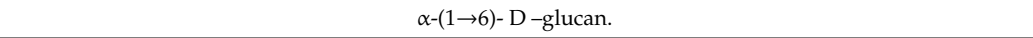 & \\
\hline 11 & LBP3a-1 & 103,000 & $\begin{array}{l}\text { GalA composed of a small } \\
\text { amount of Gal and Ara }\end{array}$ & $\begin{array}{l}\text { Gel permeation chromatography, } \\
\text { NMR }\end{array}$ & Polygalacturonan with $(1 \rightarrow 4)$ - $\alpha$-glycosidic bond. & \\
\hline 12 & LBP3a-2 & 82,000 & $\begin{array}{l}\text { GalA composed of a small } \\
\text { amount of Gal and Ara }\end{array}$ & & Polygalacturonan with $(1 \rightarrow 4)-\alpha$-glycosidic bond. & \\
\hline 13 & LBLP5-A & 113,300 & & & (1 -> 3)-linked Gal, $(1$-> 4)-linked Gal, $(1$-> 3)-linked Araf, $(1$-> 5)-linked Araf, and $(1->2,4)$-linked Rhaf. & [47] \\
\hline 14 & WSP & & $\begin{array}{l}\text { Rha:Fuc:Ara:Xyl:Man:Gal:Glc } \\
\quad=1.6: 0.2: 51.4: 4.8: 1 \cdot 2: 25 \cdot 9: 7.3\end{array}$ & NMR, ESI-MS & $\begin{array}{l}\text { Backbone composed of }(1 \rightarrow 2) \text {-linked-Rha and }(1 \rightarrow 4) \text {-linked-Gal. Branches composed of }(1 \rightarrow 5) \text {-linked-Ara } \\
\text { terminated with Ara residues, and }(1 \rightarrow 4) \text {-linked-Xyl terminated with Man residues. }\end{array}$ & \\
\hline 15 & AGP & & $\begin{array}{l}\text { Rha:Ara:Xyl:Gal:Glc:GalA:GlcA } \\
\quad=3.3: 42.9: 0.3: 44: 3: 2.4: 7.0\end{array}$ & NMR & $\begin{array}{l}\text { Backbone composed of linear homogalacturonan fragments and rhamnogalacturonan fragments. Side } \\
\text { chains mainly composed of } \beta-1,6 \text { - and } \beta-1,4 \text {-galactopyranan and } \alpha-1,5 \text {-arabinofuranan. }\end{array}$ & [48] \\
\hline 16 & LBP-IV & 41,800 & $\begin{array}{l}\text { Rha:Ara:Xyl:Glc:Gal = } \\
\text { 1.61:3.82:3.44: } 7.54: 1.00\end{array}$ & DEAE-Sephadex, HPGPC, IR, UV & $\begin{array}{c}\text { Backbone composed of both } \alpha \text { - and } \beta \text { - anomeric configurations of Ara and Glc. Rha was located at terminal } \\
\text { of polysaccharide chain. }\end{array}$ & [49] \\
\hline 17 & LbGp1 & 49,100 & Ara:Gal = 5.6:1 & HPGPC & $\begin{array}{l}\text { Backbone composed of }(1 \rightarrow 6) \text {-Gal. Side chains mainly composed of }(1 \rightarrow 3) \text {-Gal/( }(\rightarrow 4) \text {-Gal and } \\
\qquad(1 \rightarrow 3) \text {-Ara/( }(1 \rightarrow 4) \text {-Ara. Ara was located at terminal of branch. }\end{array}$ & [50] \\
\hline 18 & $\mathrm{p}$-LBP & 64,000 & $\begin{array}{l}\text { Fuc:Rha:Ara:Gal:Glc:Xyl:GalA:GlcA } \\
\quad=1.00: 6.44: 54.84: 22.98: 4.05: \\
\text { 2.95:136.98:3.35 }\end{array}$ & $\begin{array}{l}\text { HPAEC-PAD, HPSEC, FT-IR, } \\
\text { GC-MS, and NMR }\end{array}$ & $\begin{array}{l}\text { Backbone composed of }(1 \rightarrow 4) \text { - } \alpha \text {-GalA. Side chains mainly composed of } \alpha-1,2 \text { - and } \alpha-1,4 \text {-Rha and } \\
\qquad \alpha-1,5 \text {-Ara. }\end{array}$ & [51] \\
\hline 19 & LBP1B-S-2 & 80,000 & $\begin{array}{l}\text { Rha:Ara:Gal:Glu = 3.13: 53.55: } \\
\text { 39.37: } 3.95\end{array}$ & DEAE Sepharose & $\begin{array}{l}\text { Backbone consisted of 1, 3-linked beta-D-Galp, 1, 6-linked beta-D-Galp and branches contained 1, 4-linked } \\
\text { beta-D-GlcpA, T-linked beta-D-Galp, 1, 6-linked beta-D-Galp, T-linked alpha-L-Araf, T-linked beta-L-Aral 1, } \\
\text { 5-linked alpha-L-Araf and T-linked beta-L-Rhap. }\end{array}$ & [52] \\
\hline 20 & LRGP1 & 56,200 & $\begin{array}{l}\text { Rha:Ara:Xyl:Man:Glu:Gal }= \\
\text { 0.65:10.71:0.33:0.67:1:10.41 }\end{array}$ & HPGPC, ESI-MS & $\begin{array}{l}\text { Backbone composed of }(1->3) \text {-linked Gal. The branches were composed of }(1->5) \text {-linked Ara, }(1-> \\
\text { 2)-linked Ara, }(1>6) \text {-linked Gal, }(1->3) \text {-linked Gal, }(1>4) \text {-linked Gal and }(1->2,4) \text {-linked Rha. }\end{array}$ & [53] \\
\hline
\end{tabular}




\section{Biological Function of LBPs}

\subsection{Antioxidant Function}

Natural bioactive compounds present good biological activities, such as antioxidant, anticancer, and other functions, because of the broad diversity of structures and functionalities [54-56]. As bioactive compounds, LBPs have good antioxidant properties [57-59]. Antioxidant activity is mainly contributed by carotenoids, flavonoids, ascorbic acid and its derivatives, and polyphenols [60,61].

The biological function of LBPs have many potential functions relative to the antioxidant activity in many tissues [62-64]. Studies have investigated the antioxidant activity of LBPs that extract with hot water and the protective effect of LBPs against tissue oxidative injury, with results showing that LBPs exhibit a good antioxidant activity and a protective effect against skin oxidative injury [65]. The antioxidant effects of LBPs extracted by hot water have been explored via an in vivo model, showing that LBP treatments can significant increase the serum levels of SOD and GSH-Px and significantly decrease MDA contents [66-69]. The antioxidant function of LBPs shows that LBPs can significantly enhance macrophage NO, phagocytic capacity, and acid phosphatase, and exhibit good antioxidant activities in vitro [70]. LBPs can significantly increase cell viability that decreases by LPS and regulate oxidative stress by inhibiting caspase-3 activation and ROS levels in vitro [71]. Studies have investigated the effects of LBPs on stressed RPE cells and have shown that LBPs can decrease ROS levels via free radical scavenging and downstream gene function to prevent ROS-induced apoptosis [72]. Antioxidant enzyme activities, GSH levels, and MDA levels in rats fed with a high-fat diet and LBPs decreased when compared with those in the control group $(p<0.01)$ [73]. The antioxidant activity and mechanisms of LBPs are shown in Table 3.

Table 3. Antioxidant activity and mechanisms of LBPs.

\begin{tabular}{|c|c|c|c|c|c|}
\hline Antioxidant Activity & Mechanisms & Dose & Experiment Model & Experiment Type & Ref \\
\hline Reduce oxidative stress & $\begin{array}{l}\text { Regulating the level of MDA, } \\
\text { SOD, GSH }\end{array}$ & 100,200 , and $400 \mathrm{mg} / \mathrm{kg}$ & Rats & In vivo & $\begin{array}{l}771, \\
74]\end{array}$ \\
\hline Against hypoxia-induced injury & Down-regulation of miR-122 & $300 \mathrm{mu} \mathrm{g} / \mathrm{mL}$ & Cells & In vitro & [75] \\
\hline $\begin{array}{l}\text { Attenuates diabetic } \\
\text { testicular dysfunction }\end{array}$ & $\begin{array}{l}\text { Upregulated p-PI3K and } \\
\text { p-Akt protein expressions }\end{array}$ & $40 \mathrm{mg} / \mathrm{kg}$ & Mice & In vivo & [76] \\
\hline Radical scavenging & Free radical scavenging & $\begin{array}{c}\text { IC 50:1.29-3.00 } \\
\mathrm{mg} / \mathrm{mL}(\mathrm{DPPH}) \\
0.39-1.10 \mathrm{mg} / \mathrm{mL} \text { (ABTS) }\end{array}$ & Chemical reagent & In vivo & [77] \\
\hline
\end{tabular}

\subsection{Immune Regulation}

Immune regulation is an important function of LBPs in people's health. Previous studies have shown that LBPs exhibit an immune-modulating function in target dendritic cells, macrophages, Tand B-lymphocytes, and natural killer (NK) cells [79]. The immune regulation of LBPs is an important function that has been studied widely in previous studies.

Dendritic cells are used to study the effects of LBPs, and results have shown that LBPs can induce the phenotypic and functional maturation of DCs via Notch signaling and promote the cytotoxicity of DC-mediated CTLs [80]. In nutritive additives, LBPs can be used as an additive in the growth of broilers, indicating that LBPs may possess the clinical efficacy for growth promotion and immunomodulation and can be used as an alternative to nutritive additive in broilers [81]. The nanoliposome technique is used to load LBPs and study their function, showing that LBPs can significantly promote splenocyte proliferation, increase the amount of CD4(+) to CD8(+) T cells, and promote the cytokine secretion of macrophages [82]. The extract of L. barbarum exhibits a significant immunomodulatory activity through the promotion effects of nitric oxide and cytokines in RAW264.7 cells [83]. The efficacies of sulfated LBPs on immune enhancements in cultured chicken are high [84]. In summary, the immune regulation and mechanism of LBPs are shown in Table 4. 
Table 4. Immune regulation activity and mechanisms of LBPs.

\begin{tabular}{|c|c|c|c|}
\hline Immune Regulation Activity & Mechanism & Experiment Type & Ref \\
\hline $\begin{array}{l}\text { Enhanced macrophage endocytic } \\
\text { and phagocytic capacities in vivo }\end{array}$ & $\begin{array}{c}\text { Activate transcription factors NFAT, AP-1, prompt CD25 expression, induce IL-2 and } \\
\text { IFN-gamma gene transcription and protein secretion }\end{array}$ & In vitro & [85] \\
\hline Regulation of immune cells & $\begin{array}{l}\text { Maintain high levels of T cells, prevent the increase of Tregs, promote infiltration of } \\
\text { CD } 8+T \text { cells }\end{array}$ & In vivo & [86] \\
\hline $\begin{array}{l}\text { Induce the phenotypic and } \\
\text { functional maturation of DCs }\end{array}$ & Upregulate the expression of Notch and Jagged and Notch targets Hes1 and Hes5 & In vitro & [80] \\
\hline $\begin{array}{l}\text { Promote the proliferation of } \\
\text { spleen cells }\end{array}$ & $\begin{array}{l}\text { Increase secretion of INF-alpha and IL-6, mRNA expression of iNOS, IL-beta and } \\
\text { IL- } 6 \text { through activating phosphorylation of ERIC, JNK, p38 and p65 }\end{array}$ & In vitro & [87] \\
\hline Increased immune organ indexes & Promote blood B and T lymphocyte proliferation & In vivo & [81] \\
\hline Improve immune responses & Stimulate CD4(+) and CD8(+) T cell proliferation & In vitro & [88] \\
\hline Enhance the immune activity & $\begin{array}{c}\text { Enhance PCV2-specific IgG antibody responses, promote Th1 cytokines (IFN-gamma } \\
\text { and TNF-alpha) and Th2 cytokine (IL-4) secretion }\end{array}$ & In vitro & [82] \\
\hline Enhance the immune activity & Inhibit cell proliferation, retard cell cycle growth, and promote apoptosis & In vitro, In vivo & [89] \\
\hline
\end{tabular}

\subsection{Antitumor Activity of LBPS}

The antitumor activity of natural products isolated from plants have been reported [90-92]. Previous studies have shown that more than 100 polysaccharides exhibit good anticancer activity via in vitro studies and in vivo animal models [93].

As natural products, LBPs exhibit potential antitumor activity [94]. Studies have shown that the anticancer activity of LBPs occurs because of their effects on cancer tissue or cancer cells. The exposure to hot water extracts of Lycium barbarum for $24 \mathrm{~h}$ made cell viability reduce to $15.31 \%$ of hepatocellular carcinoma cells, as reported in a previous study [95]. Colorectal cancer is one of the most common cancers worldwide, with a study showing that the treatment of LBP $(5000 \mathrm{mg} / \mathrm{L})$ can decrease cell viability of SW480 and Caco-2 cells to 10\% after 5 days of treatment, and that the treatment with LBP resulted in a dose-dependent increase in the distribution of cells in the G0/G1 phase [96]. For gastric cancer cells, LBPs can inhibit the proliferation of these cells and arrest the cell cycle at the G0/G1 phase, suggesting that LBPs are candidate anticancer agents [97]. The inhibitory effect of LBPs on the growth of glioma in rats and the underlying mechanism have been explored, and results have shown that the mechanism may be related to the regulation of the blood-brain barrier and to the promotion of $C D[8]^{+}$ T cell invasion in the brain [98]. Studies on the effects of LBPs on the viability, cell cycle, and apoptosis of human hepatoma cells have demonstrated that LBPs can inhibit cell growth, arrest the cell cycle in the $S$ phase, and induce apoptosis, suggesting the antiproliferative activity of LBPs by inducing cell cycle arrest and increasing intracellular calcium in the apoptotic system [99]. The anticancer activity of LBPs is mainly due to the inhibited growth of cells, arrested cell cycle, and induced cell apoptosis. The antitumor activities of LBPs on different cancer cells are shown in Table 5. LBPs exhibit a good antitumor activity on various cancer cells.

Table 5. Antitumor activities and mechanism of LBPs.

\begin{tabular}{|c|c|c|c|c|}
\hline Antitumor Activity & Mechanism & Tumor Model & Experiment Type & Ref \\
\hline Regulate apoptosis & Induce apoptosis & MCF-7, BIU87 & In vitro & [100] \\
\hline Regulate cell cycle & Arrest the cells at the G1 phase & SW480, Caco- 2 cells & In vitro & {$[101]$} \\
\hline Regulate immune activity & Enhance immunity & Mice & In vivo & {$[84,86]$} \\
\hline
\end{tabular}

These results show that LBPs can decrease the viability of cancer cells and have inhibitory effects on cancer cells, indicating that LBPs can be used as a candidate anticancer agent in cancer treatment.

\subsection{Neuroprotective Effects of LBPS}

Natural products isolated from plants exhibit certain biological functions and have been extensively investigated because of their efficiency and biosafety. As such, they have been widely used to treat diseases. Plant extracts have been utilized to treat various functions of central nervous systems [102]. 
Polysaccharides are effective compounds from neurobiologically active plants, and many studies have demonstrated their beneficial effects, including neurological disorders [102,103].

The neuroprotective effects of LBPs on ischemic injury is mainly through the signaling pathways of NR2A activation and NR2B inhibition, and LBPs can be used to treat ischemic stroke [104]. A mouse experiment model of the neuroprotective effects of LBPs have shown that LBPs may exert neuroprotective effects and help prevent neurodegenerative diseases [105]. In modern society, visual impairments and blindness cause heavy damage on people's health. LBP treatment can significantly weaken these injuries with enhanced endogenous autophagy in the body [106]. The neuroprotective effects and molecular mechanisms of LBPs are shown in Table 6.

Table 6. Neuroprotective effects and mechanisms of LBPs.

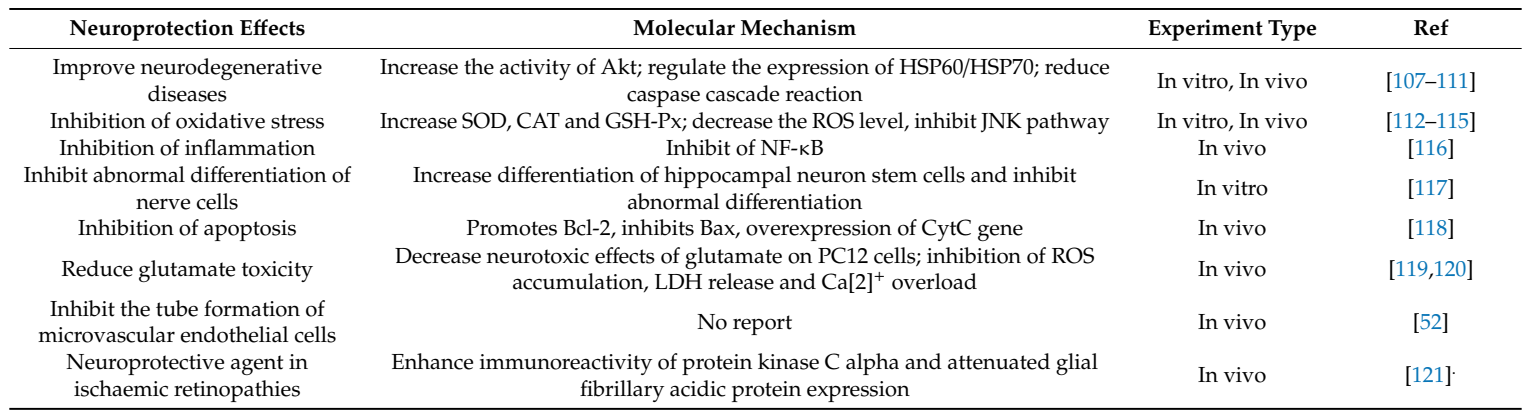

\subsection{Other Biological Activities}

The antioxidant activity, antitumor properties, immune regulation, and neuroprotective effects of LBPs were explored in in vitro and in vivo models. Besides this, LBPs also have other biological activities, such as protecting the liver from hepatotoxicity [122], alleviating dry-eye disease [123], eliciting antidiabetic effects [124], increasing cell abilities, decreasing cell morphologic impairment, protecting against ultraviolet-induced damage [122], and alleviating CCl4-induced liver fibrosis [125]. As bioactive constituents, LBPs exhibit various biological functions and show potential benefits to people's health. The other biological activities and mechanism of LBPs are summarized in Table 7.

Table 7. Other biological activities and mechanism of LBPs.

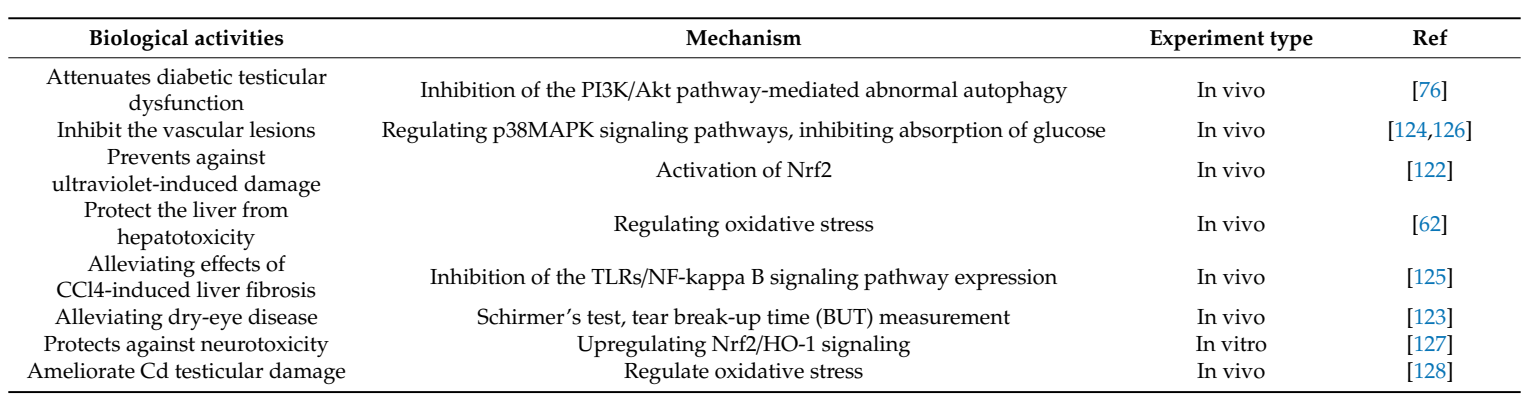

\section{Conclusions}

In China, goji berries are a traditional medicinal herb that have been used for thousand years to cure disease and improve the function of the liver, kidney, and lungs. More recently, western countries have also started cultivating Lycium barbarum L. plants, whose fruits are consumed fresh or dried. Previous reports have showed that L. barbarum fruit exhibits a wide array of pharmacological activities. This beneficial L. barbarum component consists of a complex mixture of glycoconjugates-these being LBPs - with a molecular weight range of 10-2300 kDa, water solubility, and containing a carbohydrate portion $(\geq 90 \%)$, represented by highly-branched polysaccharides. The LBP glycan backbones have been found to be mainly represented by $\alpha-(1 \rightarrow 4)$-galA, $\alpha-(1 \rightarrow 6)$-glc, $\beta-(1 \rightarrow 3)$-galp (typical of arabinogalactan

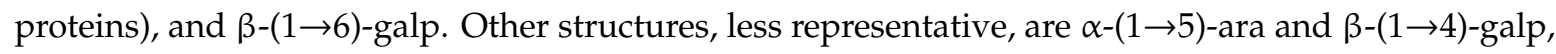


with different branching and terminal sites. The extraction methods of LBPs, including water extraction, enzyme-assisted extraction, microwave-assisted extraction, and ultrasonic-assisted extraction, produce different effects on the quality of LBPs. The biological functions of LBPs indicate that LBPs exhibits antioxidant, immunomodulation, antitumor, neuroprotection, and hepatoprotection.

LBPs are the main active substances in L. barbarum fruits and are involved in various biological functions. LBPs have great potential health benefits for further use in nutraceutical and pharmaceutical fields. The biological function of LBPs has been explored using in vitro and in vivo models but not in the human body. However, the relationship between a high-order LBP structure and bioactivities has yet to be further explored. Novel omics technologies, such as proteomics, metabolomics, and genomics, are effective in investigating the biological function of LBPs. Future works should focus on the high-order structures of LBPs, their biological function in the human body, and the relationship between their structure and bioactivity to enhance our understanding of the functional effects of LBPs. Current extraction methods give low yields and other weaknesses in the extraction of LBPs. Novel environmentally friendly and high-yielding extraction methods of LBPs should be further developed. The extraction methods and structural and biological functions of LBPs were summarized in this review to provide a useful bibliography for further investigations and applications of LBPs in medicine and food.

Author Contributions: X.T., T.L., and Z.M. conceived the idea; X.T. and T.L. write the draft; Y.L., F.Z., and G.D. edited the manuscript; all authors read and approved the final manuscript.

Funding: We gratefully acknowledge financial support from National Natural Science Foundation of China (31560477), ministry of science and technology project (KY201501005), Gansu province Science Technology funding plan through Project (17YF1WA166) and Natural Science Foundation of Gansu province (18JR3RA371).

Conflicts of Interest: The author(s) declare that they have no conflicts of interest to disclose.

$\begin{array}{ll}\text { Abbreviations } \\ \text { LBPs } & \text { Lycium barbarum polysaccharides } \\ \text { WEM } & \text { water extraction method } \\ \text { EAM } & \text { enzyme-assisted extraction method } \\ \text { MAM } & \text { microwave-assisted extraction method } \\ \text { UAM } & \text { ultrasonic-assisted extraction method } \\ \text { SEC } & \text { size exclusive chromatography } \\ \text { ESI-MS } & \text { electrospray ionization mass spectrometry } \\ \text { GC-MS } & \text { gas chromatography-mass spectrometry } \\ \text { NMR } & \text { nuclear magnetic resonance } \\ \text { HPGPC } & \text { high performance gel permeation chromatography }\end{array}$

\section{References}

1. Li, X.M. Protective effect of Lycium barbarum polysaccharides on streptozotocin-induced oxidative stress in rats. Int. J. Biol. Macromol. 2007, 40, 461-465. [CrossRef] [PubMed]

2. Amagase, H.; Farnsworth, N.R. A review of botanical characteristics, phytochemistry, clinical relevance in efficacy and safety of Lycium barbarum fruit (Goji). Food Res. Int. 2011, 44, 1702-1717. [CrossRef]

3. Wu, D.-T.; Guo, H.; Lin, S.; Lam, S.-C.; Zhao, L.; Lin, D.-R.; Qin, W. Review of the structural characterization, quality evaluation, and industrial application of Lycium barbarum polysaccharides. Trends Food Sci. Technol. 2018, 79, 171-183. [CrossRef]

4. Potterat, O. Goji (Lycium barbarum and L. chinense): Phytochemistry, Pharmacology and Safety in the Perspective of Traditional Uses and Recent Popularity. Planta Med. 2010, 76, 7-19. [CrossRef] [PubMed]

5. Wang, H.; Li, J.; Tao, W.; Zhang, X.; Gao, X.; Yong, J.; Zhao, J.; Zhang, L.; Li, Y.; Duan, J.-A. Lycium ruthenicum studies: Molecular biology, Phytochemistry and pharmacology. Food Chem. 2018, 240, 759-766. [CrossRef] [PubMed]

6. Zeng, S.; Liu, Y.; Wu, M.; Liu, X.; Shen, X.; Liu, C.; Wang, Y. Identification and validation of reference genes for quantitative real-time PCR normalization and its applications in lyceum. PLoS ONE 2014, 9, e97039. 
7. Wawruszak, A.; Czerwonka, A.; Okła, K.; Rzeski, W. Anticancer effect of ethanol Lycium barbarum (Goji berry) extract on human breast cancer T47D cell line. Nat. Prod. Res. 2015, 30, 1.

8. Tang, W.-M.; Chan, E.; Kwok, C.-Y.; Lee, Y.-K.; Wu, J.-H.; Wan, C.-W.; Chan, R.Y.-K.; Yu, P.H.-F.; Chan, S.-W. A review of the anticancer and immunomodulatory effects of Lycium barbarum fruit. Inflammopharmacology 2012, 20, 307-314. [CrossRef]

9. Zhang, Q.Y.; Chen, W.W.; Zhao, J.H.; Xi, W.P. Functional constituents and antioxidant activities of eight Chinese native goji genotypes. Food Chem. 2016, 200, 230-236. [CrossRef]

10. Yao, R.; Heinrich, M.; Weckerle, C.S. The genus Lycium as food and medicine: A botanical, ethnobotanical and historical review. J. Ethnopharmacol. 2018, 212, 50-66. [CrossRef]

11. Wang, Q.; Chen, S.; Zhang, Z. Determination of Polysaccharide Contents in Fructus Lycii. Chin. Herbal Med. 1991, 22, 67-69.

12. Lu, S.-P.; Zhao, P.-T. Chemical characterization of Lycium barbarum polysaccharides and their reducing myocardial injury in ischemia/reperfusion of rat heart. Int. J. Biol. Macromol. 2010, 47, 681-684. [CrossRef] [PubMed]

13. Xin, Y.-F.; Wan, L.-L.; Peng, J.-L.; Guo, C. Alleviation of the acute doxorubicin-induced cardiotoxicity by Lycium barbarum polysaccharides through the suppression of oxidative stress. Food Chem. Toxicol. 2011, 49, 259-264. [CrossRef] [PubMed]

14. Tian, X.M.; Wang, R.; Zhang, B.K.; Wang, C.L.; Guo, H.; Zhang, S.J. Impact of Lycium Barbarum Polysaccharide and Danshensu on vascular endothelial growth factor in the process of retinal neovascularization of rabbit. Int. J. Ophthalmol. 2013, 6, 59-61. [PubMed]

15. Gong, H.; Shen, P.; Jin, L.; Xing, C.; Tang, F. Therapeutic effects of Lycium barbarum polysaccharide (LBP) on irradiation or chemotherapy-induced myelosuppressive mice. Cancer Biother. Radiopharm. 2005, 20, 155-162. [CrossRef]

16. Chang, R.C.-C.; So, K.-F. Use of anti-aging herbal medicine, Lycium barbarum, against aging-associated diseases. What do we know so far? Cell. Mol. Neurobiol. 2008, 28, 643-652. [CrossRef]

17. He, N.; Yang, X.; Jiao, Y.; Tian, L.; Zhao, Y. Characterisation of antioxidant and antiproliferative acidic polysaccharides from Chinese wolfberry fruits. Food Chem. 2012, 133, 978-989. [CrossRef]

18. Xiao, J.; Liong, E.C.; Ching, Y.P.; Chang, R.C.; So, K.F.; Fung, M.L.; Tipoe, G.L. Lycium barbarum polysaccharides protect mice liver from carbon tetrachloride-induced oxidative stress and necroinflammation. J. Ethnopharmacol. 2012, 139, 462-470. [CrossRef]

19. Zhou, Z.Q.; Fan, H.X.; He, R.R.; Xiao, J.; Tsoi, B.; Lan, K.H.; Kurihara, H.; So, K.F.; Yao, X.S.; Gao, H. Lycibarbarspermidines A-O, New Dicaffeoylspermidine Derivatives from Wolfberry, with Activities against Alzheimer's Disease and Oxidation. J. Agric. Food Chem. 2016, 64, 2223. [CrossRef]

20. Zhang, M.; Cui, S.W.; Cheung, P.C.K.; Wang, Q. Antitumor polysaccharides from mushrooms: a review on their isolation process, structural characteristics and antitumor activity. Trends Food Sci. Technol. 2007, 18, 4-19. [CrossRef]

21. Chen, Y.; Yao, F.; Ming, K.; Wang, D.; Hu, Y.; Liu, J.J.M. Polysaccharides from Traditional Chinese Medicines: Extraction, Purification, Modification, and Biological Activity. Molecules 2016, 21, 1705. [CrossRef] [PubMed]

22. Masci, A.; Carradori, S.; Casadei, M.A.; Paolicelli, P.; Petralito, S.; Ragno, R.; Cesa, S. Lycium barbarum polysaccharides: Extraction, purification, structural characterisation and evidence about hypoglycaemic and hypolipidaemic effects. A review. Food Chem. 2018, 254, 377-389. [CrossRef] [PubMed]

23. Skenderidis, P.; Petrotos, K.; Giavasis, I.; Hadjichristodoulou, C.; Tsakalof, A. Optimization of ultrasound assisted extraction of of goji berry (Lycium barbarum) fruits and evaluation of extracts' bioactivity. J. Food Process. Eng. 2017, 40, 12. [CrossRef]

24. Zhao, C.; Yang, R.F.; Qiu, T.Q. Ultrasound-enhanced subcritical water extraction of polysaccharides from Lycium barbarum L. Sep. Purif. Technol. 2013, 120, 141-147.

25. Zhang, J.; Jia, S.Y.; Liu, Y.; Wu, S.H.; Ran, J.Y. Optimization of enzyme-assisted extraction of the Lycium barbarum polysaccharides using response surface methodology. Carbohydr. Polym. 2011, 86, 1089-1092. [CrossRef]

26. Liu, Z.G.; Dang, J.; Wang, Q.L.; Yu, M.F.; Jiang, L.; Mei, L.J.; Shao, Y.; Tao, Y.D. Optimization of polysaccharides from Lycium ruthenicum fruit using RSM and its anti-oxidant activity. Int. J. Biol. Macromol. 2013, 61, 127-134. [CrossRef] [PubMed] 
27. Reverchon, E.; de Marco, I. Supercritical fluid extraction and fractionation of natural matter. J. Supercrit. Fluids 2006, 38, 146-166. [CrossRef]

28. Ma, T.; Sun, X.; Tian, C.; Luo, J.; Zheng, C.; Zhan, J. Polysaccharide extraction from Sphallerocarpus gracilis roots by response surface methodology. Int. J. Biol. Macromol. 2016, 88, 162-170. [CrossRef]

29. Zhong-Qiua, H.U.; Liu, J.D.; Wang, B.L. Research on extraction technology of Lycium barbarum polysaccharides by the alkaline solution. J. Northwest A F Univ. Nat. Sci. Ed. 2008, 36, 173-178.

30. Luo, Q.; Yan, J.; Zhang, S. Isolation and purification of Lycium barbarum polysaccharides and its antifatigue effect. J. Hyg. Res. 2000, 29, 115-117.

31. Ji, X.L.; Peng, Q.; Yuan, Y.P.; Liu, F.; Wang, M. Extraction and physicochemical properties of polysaccharides from Ziziphus Jujuba cv. Muzao by ultrasound-assisted aqueous two-phase extraction. Int. J. Biol. Macromol. 2018, 108, 541-549. [CrossRef] [PubMed]

32. Yin, G.H.; Dang, Y.L. Optimization of extraction technology of the Lycium barbarum polysaccharides by Box-Behnken statistical design. Carbohydr. Polym. 2008, 74, 603-610. [CrossRef]

33. Liu, Y.; Gong, G.; Zhang, J.; Jia, S.; Li, F.; Wang, Y.; Wu, S. Response surface optimization of ultrasound-assisted enzymatic extraction polysaccharides from Lycium barbarum. Carbohydr. Polym. 2014, 110, 278-284. [CrossRef] [PubMed]

34. Yang, R.-F.; Zhao, C.; Chen, X.; Chan, S.-W.; Wu, J.-Y. Chemical properties and bioactivities of Goji (Lycium barbarum) polysaccharides extracted by different methods. J. Funct. Foods 2015, 17, 903-909. [CrossRef]

35. Li, X.M.; Li, X.L.; Zhou, A.G. Evaluation of antioxidant activity of the polysaccharides extracted from Lycium barbarum fruits in vitro. Eur. Polym. J. 2007, 43, 488-497. [CrossRef]

36. Muatasim, R.; Ma, H.L.; Yang, X. Effect of multimode ultrasound assisted extraction on the yield of crude polysaccharides from Lycium Barbarum (Goji). Food Sci. Technol. 2018, 38, 160-166. [CrossRef]

37. Gao, Z.; Ali, Z.; Khan, I.A. Glycerogalactolipids from the fruit of Lycium barbarum. Phytochemistry 2008, 69, 2856-2861. [CrossRef] [PubMed]

38. Ouyang, H.X.; Li, Y.Q.; Xiao, Q.W. Simultaneous determination of monosaccharides and oligosaccharides in Lycium barbarum L. by high performance liquid chromatography. Sichuan Da Xue Xue Bao. Yi Xue Ban=J. Sichuan Univ. Med. Sci. Ed. 2007, 38, 1040.

39. Yang, J.; Wei, Y.Q.; Ding, J.B.; Li, Y.L.; Ma, J.L.; Liu, J.L. Research and application of Lycii Fructus in medicinal field. Chin. Herb. Med. 2018, 10, 339-352. [CrossRef]

40. Peng, X.; Tian, G. Structural characterization of the glycan part of glycoconjugate LbGp2 from Lycium barbarum L. Carbohydr. Res. 2001, 331, 95-99. [CrossRef]

41. Huang, L.J.; Tian, G.Y.; Ji, G.Z. Structure Elucidation of Glycan of Glycoconjugate LbGp3 Isolated from the Fruit of Lycium barbarum L. J. Asian Nat. Prod. Res. 1999, 1, 259-267. [CrossRef]

42. Peng, X.M.; Huang, L.J.; Qi, C.H.; Zhang, Y.X.; Tian, G.Y. Studies on Chemistry and Immuno-modulating Mechanism of a Glycoconjugate from Lycium barbarum L. Chin. J. Chem. 2001, 19, 1190-1197. [CrossRef]

43. Zhao, C.; Li, R.; He, Y.; Chui, G. Studies on chemistry of Gouqi polysaccharides. Yie Daxue Xuebao 1997, 29, 231-232.

44. Zhang, M.; Tang, X.; Wang, F.; Zhang, Q.; Zhang, Z. Characterization of Lycium barbarum polysaccharide and its effect on human hepatoma cells. Int. J. Biol. Macromol. 2013, 61, 270-275. [CrossRef] [PubMed]

45. Zhao, C.J.; He, Y.Q.; Li, R.Z.; Cui, G.H. Chemistry and pharmacological activity of peptidoglycan from lycium barbaruml. Chin. Chem. Lett. 1996, 7, 1009-1010.

46. Duan, C.L.; Qiao, S.Y.; Wang, N.L.; Zhao, Y.M.; Qi, C.H.; Yao, X.S. Studies on the active polysaccharides from Lycium barbarum L. Yaoxue Xuebao 2001, 36, 196-199.

47. Gong, G.P.; Fan, J.B.; Sun, Y.J.; Wu, Y.M.; Liu, Y.; Sun, W.; Zhang, Y.; Wang, Z.F. Isolation, structural characterization, and antioxidativity of polysaccharide LBLP5-A from Lycium barbarum leaves. Process. Biochem. 2016, 51, 314-324. [CrossRef]

48. Redgwell, R.J.; Curti, D.; Wang, J.; Dobruchowska, J.M.; Gerwig, G.J.; Kamerling, J.P.; Bucheli, P. Cell wall polysaccharides of Chinese Wolfberry (Lycium barbarum): Part 2. Characterisation of arabinogalactan-proteins. Carbohydr. Polym. 2011, 84, 1075-1083. [CrossRef]

49. Liu, H.; Fan, Y.; Wang, W.; Liu, N.; Zhang, H.; Zhu, Z.; Liu, A. Polysaccharides from Lycium barbarum leaves: Isolation, characterization and splenocyte proliferation activity. Int. J. Biol. Macromol. 2012, 51, 417-422. [CrossRef] 
50. Wang, Z.; Liu, Y.; Sun, Y.; Mou, Q.; Wang, B.; Zhang, Y.; Huang, L. Structural characterization of LbGp1 from the fruits of Lycium barbarum L. Food Chem. 2014, 159, 137-142. [CrossRef]

51. Liu, W.; Liu, Y.; Zhu, R.; Yu, J.; Lu, W.; Pan, C.; Yao, W.; Gao, X. Structure characterization, chemical and enzymatic degradation, and chain conformation of an acidic polysaccharide from Lycium barbarum $\mathrm{L}$. Carbohydr. Polym. 2016, 147, 114-124. [CrossRef]

52. Zhou, L.; Huang, L.; Yue, H.; Ding, K. Structure analysis of a heteropolysaccharide from fruits of Lycium barbarum L. and anti-angiogenic activity of its sulfated derivative. Int. J. Biol. Macromol. 2018, 108, 47-55. [CrossRef] [PubMed]

53. Peng, Q.; Lv, X.P.; Xu, Q.S.; Li, Y.; Huang, L.J.; Du, Y.G. Isolation and structural characterization of the polysaccharide LRGP1 from Lycium ruthenicum. Carbohydr. Polym. 2012, 90, 95-101. [CrossRef]

54. Gil-Chavez, G.J.; Villa, J.A.; Ayala-Zavala, J.F.; Heredia, J.B.; Sepulveda, D.; Yahia, E.M.; Gonzalez-Aguilar, G.A. Technologies for Extraction and Production of Bioactive Compounds to be Used as Nutraceuticals and Food Ingredients: An Overview. Compr. Rev. Food Sci. Food Saf. 2013, 12, 5-23. [CrossRef]

55. Gomez-Guillen, M.C.; Gimenez, B.; Lopez-Caballero, M.E.; Montero, M.P. Functional and bioactive properties of collagen and gelatin from alternative sources: A review. Food Hydrocoll. 2011, 25, 1813-1827. [CrossRef]

56. Yildirim, N.C.; Turkoglu, S.; Yildirim, N.; Ince, O.K. Antioxidant properties of wild edible mushroom Pleurotus eryngii collected from Tunceli province of Turkey. Dig. J. Nanomater. Biostruct. 2012, 7, 1647-1654.

57. Ding, Y.; Yan, Y.M.; Peng, Y.J.; Chen, D.; Mi, J.; Lu, L.; Luo, Q.; Li, X.Y.; Zeng, X.X.; Cao, Y.L. In vitro digestion under simulated saliva, gastric and small intestinal conditions and fermentation by human gut microbiota of polysaccharides from the fruits of Lycium barbarum. Int. J. Biol. Macromol. 2019, 125, 751-760. [CrossRef] [PubMed]

58. Yu, N.; Song, N.; Liu, C.Y.; Yang, G.L. The estrogen-like protective effect of Lycium barbarum polysaccharides in reducing oxidative stress on myocardial cells from ovariectomized rats. Mol. Med. Rep. 2019, 19, 2271-2278. [CrossRef] [PubMed]

59. Zheng, G.Z.; Ben, H.J.; Li, H.Q.; Li, X.H.; Dong, T.C.; Xu, S.M.; Yan, Y.L.; Sun, B.K.; Bai, J.W.; Li, Y.S. Lycium barbarum polysaccharide reduces hyperoxic acute lung injury in mice through Nrf2 pathway. Biomed. Pharm. 2019, 111, 733-739. [CrossRef]

60. Guo, D.J.; Cheng, H.L.; Chan, S.W.; Yu, P.H.F. Antioxidative activities and the total phenolic contents of tonic Chinese Medicinal Herbs. Inflammopharmacology 2008, 16, 201-207. [CrossRef] [PubMed]

61. Wang, C.C.; Chang, S.C.; Inbaraj, B.S.; Chen, B.H. Isolation of carotenoids, flavonoids and polysaccharides from Lycium barbarum L. and evaluation of antioxidant activity. Food Chem. 2010, 120, 184-192. [CrossRef]

62. Cheng, D.; Kong, H. The effect of Lycium barbarum polysaccharide on alcohol-induced oxidative stress in rats. Molecules 2011, 16, 2542-2550. [CrossRef]

63. Zhang, Y.; Peng, B.; Wang, S.; Liang, Y.X.; Yang, J.; So, K.F.; Yuan, T.F. Image processing methods to elucidate spatial characteristics of retinal microglia after optic nerve transection. Sci. Rep. 2016, 6, 21816. [CrossRef] [PubMed]

64. Cosio, M.S.; Buratti, S.; Mannino, S.; Benedetti, S. Use of an electrochemical method to evaluate the antioxidant activity of herb extracts from the Labiatae family. Food Chem. 2006, 97, 725-731. [CrossRef]

65. Liang, B.; Jin, M.; Liu, H. Water-soluble polysaccharide from dried Lycium barbarum fruits: Isolation, structural features and antioxidant activity. Carbohydr. Polym. 2011, 83, 1947-1951. [CrossRef]

66. Niu, A.J.; Wu, J.M.; Yu, D.H.; Wang, R. Protective effect of Lycium barbarum polysaccharides on oxidative damage in skeletal muscle of exhaustive exercise rats. Int. J. Biol. Macromol. 2008, 42, 447-449. [CrossRef] [PubMed]

67. Shan, X.; Zhou, J.; Ma, T.; Chai, Q. Lycium barbarum Polysaccharides Reduce Exercise-Induced Oxidative Stress. Int. J. Mol. Sci. 2011, 12, 1081-1088. [CrossRef] [PubMed]

68. Gu, S.; Wang, P.L.; Jiang, R. A study on the preventive effect of Lycium barbarum polysaccharide on the development of alcoholic fatty liver in rats and its possible mechanisms. Zhonghua Gan Zang Bing Za Zhi= Zhonghua Ganzangbing Zazhi = Chin. J. Hepatol. 2007, 15, 204.

69. Amagase, H.; Sun, B.; Borek, C. Lycium barbarum (goji) juice improves in vivo antioxidant biomarkers in serum of healthy adults. Nutr. Res. 2009, 29, 19-25. [CrossRef]

70. Gong, G.P.; Dang, T.T.; Deng, Y.N.; Han, J.L.; Zou, Z.H.; Jing, S.; Zhang, Y.; Liu, Q.; Huang, L.J.; Wang, Z.F. Physicochemical properties and biological activities of polysaccharides from Lycium barbarum prepared by fractional precipitation. Int. J. Biol. Macromol. 2018, 109, 611-618. [CrossRef] 
71. Chen, L.; Li, W.; Qi, D.; Wang, D. Lycium barbarum polysaccharide protects against LPS-induced ARDS by inhibiting apoptosis, oxidative stress and inflammation in pulmonary endothelial cells. Free Radic Res. 2018, 52, 480-490. [CrossRef] [PubMed]

72. Liu, L.; Lao, W.; Ji, Q.S.; Yang, Z.H.; Yu, G.C.; Zhong, J.X. Lycium barbarum polysaccharides protected human retinal pigment epithelial cells against oxidative stress-induced apoptosis. Int. J. Ophthalmol. 2015, 8, 11.

73. Wu, H.T.; He, X.J.; Hong, Y.K.; Ma, T.; Xu, Y.P.; Li, H.H. Chemical characterization of lycium barbarum polysaccharides and its inhibition against liver oxidative injury of high-fat mice. Int. J. Biol. Macromol. 2010, 46, 540-543. [CrossRef] [PubMed]

74. Tang, L.J.; Bao, S.Y.; Du, Y.; Jian, Z.Y.; Wuliji, A.O.; Ren, X.; Zhang, C.H.; Chu, H.Y.; Kong, L.; Ma, H.Y. Antioxidant effects of Lycium barbarum polysaccharides on photoreceptor degeneration in the light-exposed mouse retina. Biomed. Pharm. 2018, 103, 829-837. [CrossRef] [PubMed]

75. Li, Q.J.; Zhang, Z.W.; Li, H.; Pan, X.Y.; Chen, S.S.; Cui, Z.Y.; Ma, J.; Zhou, Z.X.; Xing, B. Lycium barbarum polysaccharides protects $\mathrm{H} 9 \mathrm{c} 2$ cells from hypoxia-induced injury by down-regulation of miR-122. Biomed. Pharm. 2019, 110, 20-28. [CrossRef] [PubMed]

76. Shi, G.J.; Zheng, J.; Han, X.X.; Jiang, Y.P.; Li, Z.M.; Wu, J.; Chang, Q.; Niu, Y.; Sun, T.; Li, Y.X.; et al. Lycium barbarum polysaccharide attenuates diabetic testicular dysfunction via inhibition of the PI3K/Akt pathway-mediated abnormal autophagy in male mice. Cell Tissue Res. 2018, 374, 653-666. [CrossRef] [PubMed]

77. Skenderidis, P.; Kerasioti, E.; Karkanta, E.; Stagos, D.; Kouretas, D.; Petrotos, K.; Hadjichristodoulou, C.; Tsakalof, A. Assessment of the antioxidant and antimutagenic activity of extracts from goji berry of Greek cultivation. Toxicol. Rep. 2018, 5, 251-257. [CrossRef] [PubMed]

78. Yang, D.M.; Zhang, J.Q.; Fei, Y.F. Lycium barbarum polysaccharide attenuates chemotherapy-induced ovarian injury by reducing oxidative stress. J. Obs. Gynaecol. Res. 2017, 43, 1621-1628. [CrossRef]

79. Zhang, X.; Zhou, W.; Zhang, Y. Immunoregulation and Lycium Barbarum; Springer: Dordrecht, The Netherlands, 2015.

80. Wang, W.; Liu, M.X.; Wang, Y.; Yang, T.; Li, D.S.; Ding, F.; Sun, H.Z.; Bai, G.; Li, Q. Lycium barbarum Polysaccharide Promotes Maturation of Dendritic Cell via Notch Signaling and Strengthens Dendritic Cell Mediated T Lymphocyte Cytotoxicity on Colon Cancer Cell CT26-WT. Evid. Based Complement. Altern. Med. 2018. [CrossRef]

81. Liu, Y.L.; Yin, R.Q.; Liang, S.S.; Duan, Y.L.; Yao, J.H.; Duan, Y.L.; Yang, X.J. Effect of dietary Lycium barbarum polysaccharide on growth performance and immune function of broilers. J. Appl. Poult. Res. 2017, 26, 200-208.

82. Bo, R.N.; Zheng, S.S.; Xing, J.; Luo, L.; Niu, Y.L.; Huang, Y.; Liu, Z.G.; Hu, Y.L.; Liu, J.G.; Wu, Y.; et al. The immunological activity of Lycium barbarum polysaccharides liposome in vitro and adjuvanticity against PCV2 in vivo. Int. J. Biol. Macromol. 2016, 85, 294-301. [CrossRef] [PubMed]

83. Lin, F.Y.; Lai, Y.K.; Yu, H.C.; Chen, N.Y.; Chang, C.Y.; Lo, H.C.; Hsu, T.H. Effects of Lycium barbarum extract on production and immunomodulatory activity of the extracellular polysaccharopeptides from submerged fermentation culture of Coriolus versicolor. Food Chem. 2008, 110, 446-453. [CrossRef] [PubMed]

84. Wang, J.; Hu, Y.; Wang, D.; Liu, J.; Zhang, J.; Abula, S.; Zhao, B.; Ruan, S. Sulfated modification can enhance the immune-enhancing activity of lycium barbarum polysaccharides. Cell. Immunol. 2010, 263, 219-223. [CrossRef]

85. Chen, Z.; Kwong, H.T.B.; Chan, S.H. Activation of T lymphocytes by polysaccharide-protein complex from Lycium barbarum L. Int. Immunopharmacol. 2008, 8, 1663-1671. [CrossRef]

86. Deng, X.L.; Luo, S.; Luo, X.; Hu, M.H.; Ma, F.L.; Wang, Y.Y.; Lai, X.P.; Zhou, L. Polysaccharides from Chinese Herbal Lycium barbarum Induced Systemic and Local Immune Responses in H22 Tumor-Bearing Mice. J. Immunol. Res. 2018. [CrossRef]

87. Shen, C.Y.; Zhang, W.L.; Jiang, J.G. Immune-enhancing activity of polysaccharides from Hibiscus sabdariffa Linn. via MAPK and NF-kappa B signaling pathways in RAW264.7 cells. J. Funct. Foods 2017, 34, 118-129. [CrossRef]

88. Bo, R.N.; Sun, Y.Q.; Zhou, S.Z.; Ou, N.; Gu, P.F.; Liu, Z.G.; Hu, Y.L.; Liu, J.G.; Wang, D.Y. Simple nanoliposomes encapsulating Lycium barbarum polysaccharides as adjuvants improve humoral and cellular immunity in mice. Int. J. Nanomed. 2017, 12, 6289-6301. [CrossRef] 
89. Chen, S.Y.; Liang, L.N.; Wang, Y.; Diao, J.H.; Zhao, C.X.; Chen, G.; He, Y.F.; Luo, C.L.; Wu, X.H.; Zhang, Y. Synergistic immunotherapeutic effects of Lycium barbarum polysaccharide and interferon-alpha $2 \mathrm{~b}$ on the murine Renca renal cell carcinoma cell line in vitro and in vivo. Mol. Med. Rep. 2015, 12, 6727-6737. [CrossRef] [PubMed]

90. Cao, S.Y.; Li, Y.; Meng, X.; Zhao, C.N.; Li, S.; Gan, R.Y.; Li, H.B. Dietary natural products and lung cancer: Effects and mechanisms of action. J. Funct. Foods 2019, 52, 316-331. [CrossRef]

91. Yuan, Q.X.; Zhao, L.Y. The Mulberry (Morus alba L.) Fruit-A Review of Characteristic Components and Health Benefits. J. Agric. Food Chem. 2017, 65, 10383-10394. [CrossRef]

92. Khan, T.; Date, A.; Chawda, H.; Patel, K. Polysaccharides as potential anticancer agents-A review of their progress. Carbohydr. Polym. 2019, 210, 412-428. [CrossRef] [PubMed]

93. Chen, Y.; Hu, M.; Wang, C.; Yang, Y.; Chen, J.; Ding, J.; Guo, W. Characterization and in vitro antitumor activity of polysaccharides from the mycelium of Sarcodon aspratus. Int. J. Biol. Macromol. 2013, 52, 52-58. [CrossRef] [PubMed]

94. Kwok, S.S.; Bu, Y.S.; Lo, A.C.Y.; Chan, T.C.Y.; So, K.F.; Lai, J.S.M.; Shih, K.C. A Systematic Review of Potential Therapeutic Use of Lycium Barbarum Polysaccharides in Disease. Biomed. Res. Int. 2019. [CrossRef] [PubMed]

95. Chao, C.J.; Chiang, S.W.; Wang, C.C.; Tsai, Y.H.; Wu, M.S. Hot water-extracted Lycium barbarum and Rehmannia glutinosa inhibit proliferation and induce apoptosis of hepatocellular carcinoma cells. World J. Gastroenterol. 2006, 12, 4478-4484. [CrossRef] [PubMed]

96. Mao, F.; Xiao, B.; Jiang, Z.; Zhao, J.; Huang, X.; Guo, J. Anticancer effect of Lycium barbarum polysaccharides on colon cancer cells involves G0/G1 phase arrest. Med. Oncol. 2011, 28, 121-126. [CrossRef] [PubMed]

97. Miao, Y.; Xiao, B.X.; Jiang, Z.; Guo, Y.A.; Mao, F.; Zhao, J.W.; Huang, X.; Guo, J.M. Growth inhibition and cell-cycle arrest of human gastric cancer cells by Lycium barbarum polysaccharide. Med. Oncol. 2010, 27, 785-790. [CrossRef] [PubMed]

98. Wang, J.; Zou, Y.; Yi, L.I.; Qiao, W.U.; Zhang, B.; Liu, H.; Zhao, W.; Shen, B.; Neurosurgery, D.O. Lycium barbarum polysaccharide inhibits the growth of rat glioma by regulating the blood-brain barrier. Tumor 2018, 38, 102-110.

99. Zhang, M.; Chen, H.X.; Huang, J.; Li, Z.; Zhu, C.P.; Zhang, S.H. Effect of lycium barbarum polysaccharide on human hepatoma QGY7703 cells: Inhibition of proliferation and induction of apoptosis. Life Sci. 2005, 76, 2115-2124. [CrossRef] [PubMed]

100. Shen, L.; Du, G. Lycium barbarum polysaccharide stimulates proliferation of MCF-7 cells by the ERK pathway. Life Sci. 2012, 91, 353-357. [CrossRef] [PubMed]

101. Chen, F.; Ran, L.W.; Mi, J.; Yan, Y.M.; Lu, L.; Jin, B.; Li, X.Y.; Cao, Y.L. Isolation, Characterization and Antitumor Effect on DU145 Cells of a Main Polysaccharide in Pollen of Chinese Wolfberry. Molecules 2018, 23, 13. [CrossRef]

102. Gao, Q.H.; Fu, X.; Zhang, R.; Wang, Z.; Guo, M. Neuroprotective effects of plant polysaccharides: A review of the mechanisms. Int. J. Biol. Macromol. 2017, 106, S0141813017313600. [CrossRef]

103. Nelson, E.D.; Ramberg, J.E.; Best, T.; Sinnott, R.A.J.N.N. Neurologic effects of exogenous saccharides: A review of controlled human, animal, and in vitro studies. Nutr. Neurosci. 2012, 15, 149-162. [CrossRef] [PubMed]

104. Shi, Z.S.; Zhu, L.H.; Li, T.T.; Tang, X.Y.; Xiang, Y.H.; Han, X.J.; Xia, L.X.; Zeng, L.; Nie, J.H.; Huang, Y.X.; et al. Neuroprotective Mechanisms of Lycium barbarum Polysaccharides Against Ischemic Insults by Regulating NR2B and NR2A Containing NMDA Receptor Signaling Pathways. Front. Cell. Neurosci. 2017, 11, 16. [CrossRef] [PubMed]

105. Hu, X.; Qu, Y.; Chu, Q.; Li, W.; He, J. Investigation of the neuroprotective effects of LyciumÂ barbarum water extract in apoptotic cells and Alzheimer's disease mice. Mol. Med. Rep. 2018, 17, 3599-3606. [PubMed]

106. Bie, M.; Lv, Y.; Ren, C.; Xing, F.; Cui, Q.; Xiao, J.; So, K.F. Lycium barbarum polysaccharide improves bipolar pulse current-induced microglia cell injury through modulating autophagy. Cell Transplant. 2015, 24, 419-428. [CrossRef] [PubMed]

107. Fang, F.; Peng, T.; Yang, S.; Wang, W.; Zhang, Y.; Li, H. Lycium barbarum polysaccharide attenuates the cytotoxicity of mutant huntingtin and increases the activity of AKT. Int. J. Dev. Neurosci. 2016, 52, 66-74. [CrossRef] [PubMed] 
108. Yang, M.; Ding, J.; Zhou, X.; Zhang, X.; Tao, H.; Wang, Y.; Li, G.J.B.R. Effects of lycium barbarum polysaccharides on neuropeptide $\mathrm{Y}$ and heat-shock protein 70 expression in rats exposed to heat. Biomed. Rep. 2014, 2, 687. [CrossRef]

109. Teng, P.; Li, Y.H.; Cheng, W.J.; Zhou, L.; Shen, Y.; Wang, Y. Neuroprotective effects of Lycium barbarum polysaccharides in lipopolysaccharide-induced BV2 microglial cells. Mol. Med. Rep. 2013, 7, 1977-1981. [CrossRef]

110. Ho, Y.S.; Yu, M.S.; Yang, X.F.; So, K.F.; Yuen, W.H.; Chang, R.C.C. Neuroprotective Effects of Polysaccharides from Wolfberry, the Fruits of Lycium barbarum, Against Homocysteine-induced Toxicity in Rat Cortical Neurons. J. Alzheimers Dis. 2010, 19, 813-827. [CrossRef]

111. Zhao, W.; Pan, X.; Li, T.; Zhang, C.; Shi, N.J.O.M. Cellular Longevity, Lycium barbarum Polysaccharides Protect against Trimethyltin Chloride-Induced Apoptosis via Sonic Hedgehog and PI3K/Akt Signaling Pathways in Mouse Neuro-2a Cells. Oxidative Med. Cell. Longev. 2016, 2016, 9826726. [CrossRef]

112. Zhao, Z.K.; Yu, H.L.; Liu, B.; Wang, H.; Luo, Q.; Ding, X.G. Antioxidative mechanism of Lycium barbarum polysaccharides promotes repair and regeneration following cavernous nerve injury. Neural Regen. Res. 2016, 11, 1312-1321.

113. Di, Y.; Suk-Yee, L.; Chung-Man, Y.; Chuen-Chung, C.R.; Kwok-Fai, S.; David, W.; Lo, A.C. Lycium barbarum extracts protect the brain from blood-brain barrier disruption and cerebral edema in experimental stroke. PLOS ONE 2012, 7, e33596.

114. Olatunji, O.J.; Chen, H.; Zhou, Y.J.N.L. Lycium chinensis Mill attenuates glutamate induced oxidative toxicity in PC12 cells by increasing antioxidant defense enzymes and down regulating $\mathrm{ROS}$ and $\mathrm{Ca}^{2+}$ generation. Neurosci. Lett. 2016, 616, 111-118. [CrossRef] [PubMed]

115. Li, H.; Liang, Y.; Chiu, K.; Yuan, Q.; Lin, B.; Chang, R.C.-C.; So, K.-F. Lycium Barbarum (Wolfberry) Reduces Secondary Degeneration and Oxidative Stress, and Inhibits JNK Pathway in Retina after Partial Optic Nerve Transection. PLoS ONE 2013, 8, e68881. [CrossRef]

116. Zhu, J.; Zhang, Y.; Shen, Y.; Zhou, H.; Yu, X. Lycium barbarum polysaccharides induce Toll-like receptor 2and 4-mediated phenotypic and functional maturation of murine dendritic cells via activation of NF-кB. Mol. Med. Rep. 2013, 8, 1216-1220. [CrossRef] [PubMed]

117. Pavan, B.; Capuzzo, A.; Forlani, G. High glucose-induced barrier impairment of human retinal pigment epithelium is ameliorated by treatment with Goji berry extracts through modulation of cAMP levels. Exp. Eye Res. 2014, 120, 50-54. [CrossRef]

118. Tengfei, W.; Yuxiang, L.; Yongsheng, W.; Ru, Z.; Lin, M.; Yinju, H.; Shaoju, J.; Juan, D.; Chengjun, Z.; Tao, S.; et al. Lycium barbarum polysaccharide prevents focal cerebral ischemic injury by inhibiting neuronal apoptosis in mice. PLoS ONE 2014, 9, e90780.

119. Hynd, M.R.; Scott, H.L.; Dodd, P.R. Glutamate-mediated excitotoxicity and neurodegeneration in Alzheimer's disease. Neurochem. Int. 2004, 45, 583-595. [CrossRef]

120. Zhu, Y.; Zhao, Q.; Gao, H.; Peng, X.; Wen, Y.; Dai, G. Lycium barbarum polysaccharides attenuates $\mathrm{N}$-methy-N-nitrosourea-induced photoreceptor cell apoptosis in rats through regulation of poly (ADP-ribose) polymerase and caspase expression. J. Ethnopharmacol. 2016, 191, 125-134. [CrossRef]

121. Yang, D.; So, K.F.; Lo, A.C.Y. Lycium barbarum polysaccharide extracts preserve retinal function and attenuate inner retinal neuronal damage in a mouse model of transient retinal ischaemia. Clin. Exp. Ophthalmol. 2017, 45, 717-729. [CrossRef]

122. Liang, B.; Peng, L.; Li, R.; Li, H.; Mo, Z.; Dai, X.; Jiang, N.; Liu, Q.; Zhang, E.; Deng, H.J.C.; et al. Lycium barbarum polysaccharide protects HSF cells against ultraviolet-induced damage through the activation of Nrf2. Cell. Mol. Biol. Lett. 2018, 23, 18. [CrossRef] [PubMed]

123. Chien, K.J.; Horng, C.T.; Huang, Y.S.; Hsieh, Y.H.; Wang, C.J.; Yang, J.S.; Lu, C.C.; Chen, F.A. Effects of Lycium barbarum (goji berry) on dry eye disease in rats. Mol. Med. Rep. 2018, 17, 809-818. [CrossRef] [PubMed]

124. Wang, G.; Ju, S.; Yang, B.H.; Yan, C.C.; Cao, X.; Zhang, X.F.; Wang, N.; Lian, X.T. Inhibitory effects and related mechanisms of lycium barbarum polysaccharides on vascular lesions in type 2 diabetes mellitus. Int. J. Clin. Exp. Med. 2018, 11, 10660-10666.

125. Gan, F.; Liu, Q.; Liu, Y.H.; Huang, D.; Pan, C.L.; Song, S.Q.; Huang, K.H. Lycium barbarum polysaccharides improve CCl4-induced liver fibrosis, inflammatory response and TLRs/NF-kappa B signaling pathway expression in wistar rats. Life Sci. 2018, 192, 205-212. [CrossRef] 
126. Tang, H.L.; Chen, C.; Wang, S.K.; Sun, G.J. Biochemical analysis and hypoglycemic activity of a polysaccharide isolated from the fruit of Lycium barbarum L. Int. J. Biol. Macromol. 2015, 77, 235-242. [CrossRef] [PubMed]

127. Cao, S.M.; Du, J.L.; Hei, Q.H. Lycium barbarum polysaccharide protects against neurotoxicity via the Nrf2-HO-1 pathway. Exp. Ther. Med. 2017, 14, 4919-4927. [CrossRef] [PubMed]

128. Varoni, M.V.; Gadau, S.D.; Pasciu, V.; Baralla, E.; Serra, E.; Palomba, D.; Demontis, M.P. Investigation of the effects of Lycium barbarum polysaccharides against cadmium induced damage in testis. Exp. Mol. Pathol. 2017, 103, 26-32. [CrossRef]

(C) 2019 by the authors. Licensee MDPI, Basel, Switzerland. This article is an open access article distributed under the terms and conditions of the Creative Commons Attribution (CC BY) license (http://creativecommons.org/licenses/by/4.0/). 